\title{
Interkasi Simbiolik dalam Komunikasi Pemasaran Terpadu di PT. Creative Motion Pctures: Studi Kasus Komunikasi Pemasaran Film Once Upon a Time in Indonesia
}

\author{
Ricardo Silenzie, Muhammad Adi Pribadi \\ ricardosilenzie@gmail.com,adip@fikom.untar.ac.id \\ Fakultas Ilmu Komunikasi Universitas Tarumanagara
}

\begin{abstract}
Integrated marketing communication planning in film marketing activities is implemented as a sales solution and promotes a film title to the public in a variety of effective and interactive ways in which the message in the film can touch the appropriate target audience. PT. Creative Motion Pictures is a film company that uses an integrated marketing communication planning formula to meet the needs of its audience. PT. Creative Motion Pictures formulas when planning marketing communication. The influence of symbolic interaction has a major contribution in the marketing communication planning of PT. Creative Motion Pictures. This research uses a qualitative methodology with a case study method. Data collection was done by participant observation, in-depth interviews with PT. Creative Motion Pictures. The conclusion of this research is that it has 4 stages of integrated marketing communication planning namely Film Products, Target Market, Promotion, Distribution. At all stages there are symbolic interactions such as language selection, organizational regulations, and company vision.
\end{abstract}

Keywords: case study, integrated marekting communication, qualitative, symbolic interaction.

\begin{abstract}
Abstrak
Perencanaan komunikasi pemasaran terpadu dalam kegiatan pemasaran film diterapkan sebagai solusi penjualan dan mempromosikan sebuah judul film kepada masyarakat dengan berbagai cara yang efektif dan interaktif dimana pesan dalam film bisa menyentuh target audience yang sesuai. PT. Creative Motion Pictures merupakan perusahaan film yang menggunakan formula perencanaan komunikasi pemasaran terpadu untuk memenuhi kebutuhan penontonnya. PT. Creative Motion Pictures formula-formula yang ketika melakukan perancanaan komunikasi pemasaran. Interaksi simbolik memiliki kontribusi yang besar dalam perencanaan komunikasi pemasaran PT. Creative Motion Pictures. Penelitian ini menggunakan metodologi kualitatif dengan metode studi kasus. Pengumpulan data dilakukan dengan observasi partisipan, wawancara yang mendalam dengan tim PT. Creative Motion Pictures. Kesimpulan dari penelitian ini yakni memiliki 4 tahapan perencanaan komunikasi pemasaran terpadu yaitu Produk Film, Target Pasar, Promosi,Pendistribusian. Pada semua tahapan tersebut terdapat interaksi lambinglambang seperti, pemilihan bahasa,peraturan organisasi, sampai visi perusahaan.
\end{abstract}

Kata Kunci: interaksi simbolik, komunikasi pemasaran terpadu, kualitatif, studi kasus. 


\section{Pendahuluan}

Industri perfilman indonesia sangat berkembang dari masa ke masa,banyak juga film-film bergenre drama, horor, action, menghiasi layar perfilman tanah air maupun dunia. Begitu banyaknya film yang diproduksi membuat masyarakat memiliki banyak pilihan dalam memilih film yang akan ditonton,dan tentunya membuat persaingan di industri perfilman pun makin ketat karena banyaknya kompetitor,ditambah lagi banyak nya film dari luar negeri yang datang dan memiliki porsi lebih besar bagi penikmat film. Oleh sebab itu perlu dilakukannya kegiatan perencanaan dalam kegiatan pendistribusian suatu film layar lebar.rumah produksi Creative Motion Pictures merupakan salah satu rumah produksi yang sering memproduksi film layar lebar untuk proyek dalam negeri maupun luar negeri. Creative Motion Pictures sendiri memiliki perusahaan cabang di singapura,amerika dan di indonesia,Creative Motion Pictures sadar bahwa banyak tantangan ketika terjun kedalam industri hiburan perfilman,ditambah lagi target market dari film produksi Creative Motion Pictures sendiri untuk skala internasional dan nasional. Hal ini juga yang menjadi dasar dalam pertimbangan dalam pemilihan setiap judul yang diproduksi oleh Creative Motion Pictures karena penentuan judul,cerita,tema,dan pemain menjadi hal penting dalam proses penjualan film tersebut.Pemilihan judul dalam setiap judul film merupakan Significant Symbol bagi penonton yang melihat judul dari film Creative Motion Pictures yakni Once Upon A Time In Indonesia.Pada Strategi komunikasi pemasaran bagi rumah produksi film layar lebar menjadi sarana strategi bisnis produser film untuk membantu penyebaran informasi mengenai penayangan sebuah film, yang dikemas melalui kegiatan dengan pers,media konvensional maupun digital di era sekarang ini, sehingga film yang siap diluncurkan bisa dikenal dan meningkatkan kesadaran akan produk film yang sedang rilis,meyakinkan penonton bahwa produk film yang ditunggu merupakan pilihan film yang layak dan menarik untuk di tonton.

Hal ini merupakan tugas bagi seorang marketing dari sebuah rumah produksi yang salah satunya ialah menyiapkan strategi komunikasi mengenai hasil produksi film yang akan ditayangkan. Sedangkan tujuan lain dari kegiatan komunikasi pemasaran ialah adanya respon dari audience/penonton berupa keinginan untuk menonton atau membeli tiket dari film yang akan di tayangkan di bioskop.di sisi lain.

Kolaborasi antara pekerja seni dan divisi marketing yang baik diharapkan dapat membangun awareness akan sebuah film rumah produksi creative motion pictures dan memberikan kesan yang baik akan produk film yang. Dalam beberapa hal, kegiatan komunikasi pemasaran dianggap efektif untuk mencapai publisitas dalam proses publikasi sebuah produk khususnya film layar lebar, karena memiliki kemampuan untuk menarik atau membujuk dan sekaligus mendidik masyarakat atau publiknya.

Manfaat dari kegiatan komunikasi pemasaran dalam perkembanganya dirasakan cukup efektif dan efisien, karena dapat menyebarkan pesan atau informasi selain itu bisa membujuk (persuasive approach)serta ditambahnya kecanggihan ilmu pengetahuan teknologi informasi yang dipergunakan oleh media digital yang sudah berkembang dengan pesat,dan membuat kegiatan komunikasi pemasaran ini memiliki asas manfaat yang berarti terhadap bauran pemasaran (marketing mix) yang berfokus pada unsur promosi sebuah film. 
Ricardo Silenzie, Muhammad Adi Pribadi: Interkasi Simbiolik dalam Komunikasi Pemasaran Terpadu di PT. Creative Motion Pctures : Studi Kasus Komunikasi Pemasaran Film Once Upon a Time in Indonesia

keberhasilan strategi komunikasi pemasaran yang diterapkan dalam film adalah seberapa besar media massa konvensional,elektronik serta digital dan masyarakat untuk mempublikasikan film dan memberikan feedback positif dari film yang akan rilis, dan tentunya pada banyak jumlah penonton yang diraih. Keberhasilan film mortal enemies produksi PT.creative motion pictures pada tahun 2011 yakni tayang di 16 negara asia dan sejumlah negara Eropa,serta pendistribusian di Amerika dan Eropa oleh pihak LIONSGATE (salah satu distributor ternama Hollywood) menunjukan pentingnya strategi komunikasi pemasaran dalam kesuksesan sebuah karya film layar lebar. Untuk mendukung fokus penelitian ini maka dibuatlah pertanyaan penelitian yang terdiri dari perencanaan strategi komunikasi pemasaran, implementasi strategi komunikasi pemasaran Creative motion pictures pada pemasaran film once upon a time in indonesia.

\section{Metode Penelitian}

Penelitian ini menggunakan pendekatan penelitian kualitatif dengan metode peneltian studi kasus Sedangkan mengenai Objek penelitian menurut Sugiyono (2016) adalah suatu atribut atau sifat atau nilai dari orang, objek atau kegiatan yang mempunyai variasi tertentu yang ditetapkan oleh peneliti untuk dipelajari dan kemudian ditarik kesimpulannyadan lebih menekankan pada proses, penelitian kualitatif lebih menekankan pada hubungan antar variable objek yang diteliti, objek penelitian dalam penelitian kualitatif bersifat interaktif yang artinya saling mempengaruhi. Adapun obyek penelitian pada penelitian ini adalah mengenai peran interaksi simbolik dan perencanaan komunikasi pemasaran film Once Upon A Time In Indonesia di PT. Creative Motion Pictures

Penelitian ini dilakukan untuk mengetahui peran interaksi simbolik dalam komunikasi pemasaran terpadu yang akan dilakukan oleh PT.Creative Motion Pictures untuk meningkatkan awareness dan menarik konsumen dalam film Once Upon A Time in Indonesia. Maka dari itu peneliti menggunakan metode penelitian kualitatif sebagai metode penelitian yang digunakan Lalu selanjutnya mengenai komunikasi pemasaran menurut Pribadi, Suganda, Venus, dan Susanto (2018) mendefinisikan komunikasi pemasaran merupakan hasil penyatuan. Dari asalnya sebuah pemaknaan oleh setiap pemangku kepentingan agar menghasilkan satu tema komunikasi yang sesuai dan konsisten untuk ditujukan kepada khalayak sasaran akan menjadi acuan sehingga mampu menjabarkan kegiatan pembentukan perencanaan komunikasi pemasaran yang diterapkan pada PT. Creative Motion Pictures mengenai bagaimana melakukan promosi atau pemasaran mengenai produk .

\section{Hasil Temuan dan Diskusi}

Sesuai dengan visi dan misi yang tertulis. Visi dan misi perusahaan tersebut sejalan dengan konsep Generalized others yang dipaparkan oleh mead karena visi dan misi perusahaan karyawan perusahaan PT.Creative Motion Pictures harus mau tidak mau untuk ikut dalam aturan yang sudah ditentukan sebagai kebijakan yang diakui dan diikuti bersama tim, sehingga PT . Creative Motion Pictures bisa bekerja sama untuk bisa mencapai target perusahaan atau organisasi yakni "mempertahankan standar kualitas film yang tinggi dalam pembuatan film asia" dijadikan suatu keyakinan yang memacu semangat dan menyelaraskan kinerja dari para anggota tim demi mencapai visi perusahaan. 
Tujuan tersebut mendorong PT.Creative Motion Pictures untuk mengikuti berbagai ajang festival film dunia,terbukti bahwa dengan menetapkan tujuan perusahaan secara perlahan tapi pasti PT.Creative Motion Pictures terus meningkatkan peringkatnya di dunia perfilman mancanegara.Tujuan jangka pendek yang ada di PT.Creatiuve Motion Pictures tersebut sejalan dengan pemikiran Mead mengenai konsep Generalized others dalam teori interaksi simbolik yang dijelaskan bahwa tiap anggota atau karyawan perusahaan harus bekerja sama untuk meraih target perusahaan secara bersama-sama. Hal tersebut juga berkaitan dengan konsep Efek Pygmalion oleh Mead yaitu dengan berbagai festival penghargaan yang dimenangkan oleh crew Creative Motion Pictures tersebut membuat tim PT. Creative Motion Pictures semakin mempunyai tujuan dan semangat yang besar dan percaya diri dalam melangkah di industry perfilman untuk terus meningkatkan karya film yang semakin berkualitas. Mead ( dalam west \& turner,2008)

Pictures (CMP) merupakan film yang memproduksi film-film layar lebar yang telah dipadukan dengan strategi Intergrated Marketing Communication untuk memaksimalkan tingkat keberhasilan penjualan film dalam industry perfilman nasional maupun internasional. Didirikan oleh Asun Mawardi ,Creative Motion Pictures (CMP) adalah gagasan Asun Mawardi, PhD CMP adalah perusahaan produksi independen yang kreatif dan dinamis yang mengembangkan dan memproduksi konten hiburan berkualitas tinggi di semua aspek film dan media baru untuk pasar domestic dan internasional. Proyek pertama CMP, “ The Black Magic “ adalah film thriller psikologis yang melibatkan actor dari Amerika Serikat, Indonesia,dan Thailand. Proyek ini memenuhi tujuan CMP untuk menghasilkan film yang menjembatani kesenjangan pemahaman antara Timur dan Barat. " Fokus pada setiap proyek adalah mempertahankan suara yang uniik sambil menceritakan kisah hebat yang berkomunikasi dan terhubung dengan audiens.

\section{Visi dan Misi}

Untuk menciptakan perusahaan produksi internasional yang menghasilkan film berbahasa inggris dan asia berkualitas tinggi menggunakan metode produksi asia yang hemat biaya sambil mempertahankan standar kualitas film yang tinggi,sehingga memaksimalkan margin keuntungan dalam pembuatan film asia.

Tagline PT.Creative Motion Pictures To create an international production company that produces high quality English and Asian dijadikan semangat tersendiri yang diresapi oleh seluruh anggota tim sehingga selalu bersinergi dalam melakukan segala pekerjaan. Filosofi dan tagline yang terdapat pada PT. Creative Motion Pictures sejalan dengan konsep Generalized others yang dipaparkan Mead yaitu aturan yang diakui oleh setiap tim yang dijadikan panutan dalam setiap kegiatan kerja 
Ricardo Silenzie, Muhammad Adi Pribadi: Interkasi Simbiolik dalam Komunikasi Pemasaran Terpadu di PT. Creative Motion Pctures : Studi Kasus Komunikasi Pemasaran Film Once Upon a Time in Indonesia

\section{Logo}

Logo dan nama dari PT. Creative Motion Pictures mencerminkan filosofi yang mendalam bagi perusahaan. Berikut ini adalah visualisasi dari logo PT. Creative Motion Pictures

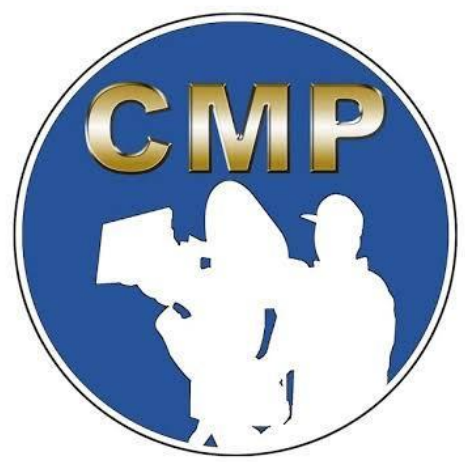

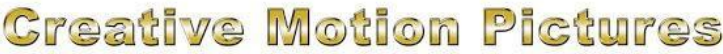

\section{Gambar 4.1 Logo PT Creative Motion Pictures Indonesia \& Amerika}

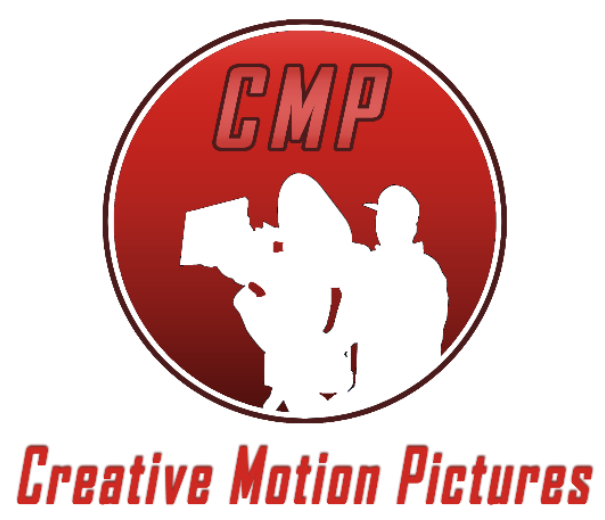

\section{Gambar 4.2 Logo PT Creative Motion Pictures \\ China}

Logo dibuat untuk kemudahan berkomunikasi dengan distributor dan target khalayak mengingat merek berasal dari China dan Amerika, penggunaan Bahasa Inggris merupakan Significant symbol bagi distributor dan penonton yang ada di China dan Amerika. 


\section{Simpulan}

PT. Creative Motion Pictures merupakan perusahaan film yang memiliki market mulai dari skala nasional dan internasional, banyak projek film layar lebar yang sudah diproduksi oleh Creative Motion Pictures,dan banyak juga kerja sama dengan distributor ternama di hollywoord seperti distributor LionsGate yang sudah langganan untuk membeli produk film produksi PT.Creative Motion Pictures,film Once Upon A Time In Indonesia yang direncanakan rilis di pertengahan tahun 2020 diharapkan akan memberikan kepuasan kepada para penonton baik dalam negeri maupun luar negeri.Target pasar PT.Creative Motion Pictures pun beragam,mulai dari penonton di indonesia hingga penonton dari benua Asia, Eropa hingga Amerika, dan juga pasar dari film-film produksi Creative Motion Pictures sendiri juga meliputi hak siar atau license yang diberika perusahaan kepada pembeli hak siar dari film Once Upon A Time In Indonesia,mulai dari stasiun televisi, video on demand seperti Netflix, hooq, Viu. Strategi promosi yang dilakukannya pun beragam mulai dari media konvensional hinggal digital bahkan sampai ke sosial media,itu semua dilakukan demi membangun awareness untuk projek film Once Upon A Time Indonesia, sehingga nantinya diharapkan film ini dapat dinikmati oleh khalayak luas dan juga mendapat apresiasi dari masyarakat .

\section{Ucapan Terima Kasih}

Penulis mengucapkan terimakasih banyak kepada kawan-kawan PT. Creative Motion Pictures yang sudah membantu dalam memberikan informasi dan sudah jadi menjadi informan

\section{Daftar Pustaka}

Sugiyono. (2016). Memahami Penelitian Kualitatif. Bandung: Alfabeta.

Pribadi, Muhammad Adi, Suganda, Venus \& Susanto, Eko Harry (2018). Dinamika Perusahaan Periklanan Indonesia: Studi Kasus Komunikasi dan Budaya Organisasi Dwi Sapta IMC dan Fortune Indonesia. Disertasi Universitas Padjajaran. Bandung: Universitas Padjajaran. 